\title{
Abnormal Glucose Metabolism in Skin Fibroblasts Cultured from a Patient with a New Syndrome of Ketoacidemia
}

\author{
J. Tyson Tildon ${ }^{[33}$, Allan T. Leffler, II, Marvin Cornblath, and Joseph Stevenson \\ Department of Pediatrics, University of Maryland School of Medicine, Baltimore, and Research Department, Rosewood \\ State Hospital, Owings Mills, Maryland, USA
}

\section{Extract}

Studies of substrate oxidation by cultured skin fibroblasts from an infant $(C C)$ with severe recurrent episodes of ketoacidosis showed normal rates of oxidation of propionate (CC 55. \pm 8 versus control $65 \pm 13 \mu \mu \mathrm{moles} / \mathrm{mg}$ protein $/ \mathrm{hr}$ ), and succinate (73. \pm 16 versus $45 \pm 8 \mu \mu \mathrm{moles} / \mathrm{mg}$ protein $/ \mathrm{hr}$ ).

In contrast, both oxidation and uptake of glucose by these cells were decreased in comparison with controls. Essentially neither glucose- $6-{ }^{14} \mathrm{C}$ nor glycerol-U $-{ }^{14} \mathrm{C}$ was converted to ${ }^{14} \mathrm{CO}_{2}$ by fibroblasts of the patient, and glucose- $1-{ }^{14} \mathrm{C}$ was oxidized at $45-65 \%$ of control rates. In the absence of glucose, oxidation of pyruvate- $2-{ }^{14} \mathrm{C}$ did not differ from that of normal controls (710 versus $940 \mu \mu \mathrm{moles} / \mathrm{mg}$ protein $/ \mathrm{hr}$ ). In the presence of $2.5 \mathrm{~mm}$ glucose, however, fibroblasts of the patient did not show the expected decrease in pyruvate- $2-{ }^{14} \mathrm{C}$ oxidation whereas control cells showed a fourfold decrease. Studies of glucose uptake demonstrated that with glucose as the only substrate extended incubation periods of 12-18 hr were necessary before the cells of the patient began to utilize measurable quantities of glucose.

The results of the metabolic studies in skin fibroblasts, when viewed in conjunction with the clinical manifestations and laboratory studies, have excluded the known causes of infantile ketoacidosis. The data reported indicate a correlation of this form of ketoacidosis with a block in the terminal pathway of glycolysis.

\section{Speculation}

A defect in glycolysis may produce intracellular hypoglycemia resulting in the activation of unknown mechanisms in peripheral tissue that initiate lipolysis and ketosis. It could also be that a yet undefined block in ketoacid metabolism might result in the observed irregular glucose oxidation. The basic abnormality may be a result of an inbalance in redox cofactors, an absence of a critical intermediate, or a reduction of an end product. These possibilities are currently being investigated.

\section{Introduction}

An infant was recently described with persistent ketonuria and recurrent episodes of severe ketoacidosis lasting 3-4 days, precipitated by stress such as dehydration or infection or by dietary protein $[3,4]$. He improved dramatically after 72-96 hr of parenteral fluid therapy consisting of glucose and alkali (Fig. 1). Although his clinical course was superficially similar to that of patients with methylmalonic acidemia $[8,13,16,19]$ and 
ketotic glycinemia $[1,2,13]$, the patient was not retarded in any way; he had a normal hemogram and clid not excrete long-chain ketones in his urine. Instead, analysis of both blood and urine revealed large amounts of $\beta$-hydroxybutyrate and acetoacetate, normal glycine levels, and absence of methylmalonate. Therefore, he represented a new metabolic defect that required clefinition.

The purpose of this report is to describe metabolic studies of cultured skin fibroblasts which, in conjunction with the clinical findings, exclude known syndromes of ketosis and suggest a block in glycolysis which appears to be correlated with a persistent ketosis and an intermittent ketoacidosis.

\section{Matcrials and Methods}

Skin fibroblasts were grown from a punch biopsy specimen [30] obtained 5 weeks prior to the death of the patient. The cells were maintained in culture in 8-ounce bottles in minimal essential medium [27] with added glutamine $(1.8 \mathrm{~mm})$, penicillin $(56 \mu \mathrm{g} / \mathrm{ml})$, streptomycin $(90 \mu \mathrm{g} / \mathrm{ml})$, and fetal calf serum (10\%) [31]. Control cell lines were obtained from the foreskins of normal infants and no significant metabolic differences were observed among the four cell lines used. All cells were grown directly in $25-\mathrm{ml}$ tissue culture reaction flasks [28] and were used 4-8 clays after replating. Tests for contamination by bacteria or Mycoplasma were negative [31].

For the metabolic studies, the medium was decanted and the adherent cell layer was rinsed twice with warm Krebs-Ringer-phosphate buffer. Two milliliters of the same buffer with or without glucose $(2.5 \mathrm{~mm})$ were then added and each flask was capped with a soft rubber stopper with an attached plastic center well [28] containing fluted filter papers [24]. Radiolabeled ${ }^{14} \mathrm{C}$ substrates, $1.0 \mu \mathrm{Ci} /$ llask [29], were used without further purification. Incubations were done at $37^{\circ}$ in a Dubnoff metabolic shaker for $2 \mathrm{hr}$, except when noted otherwise.

At the end of the incubation period, $0.3 \mathrm{ml} 20 \%$ trichloroacetic acid (TCA) was injected into the flask to kill the cells and to volatilize the $\mathrm{CO}_{2}$, which was trapped in the center well containing $0.2 \mathrm{ml} 5 \mathrm{~N} \mathrm{KOH}$ added at the same time. After 60-min equlibration in the cold, the caps were removed and the center well including its contents was placed into $12 \mathrm{ml}$ dioxane base scintillation fluid for counting. Efficiencies, determined by the channels ratio technique, ranged from $40-80 \%$. Nonspecific or background radioactivity was

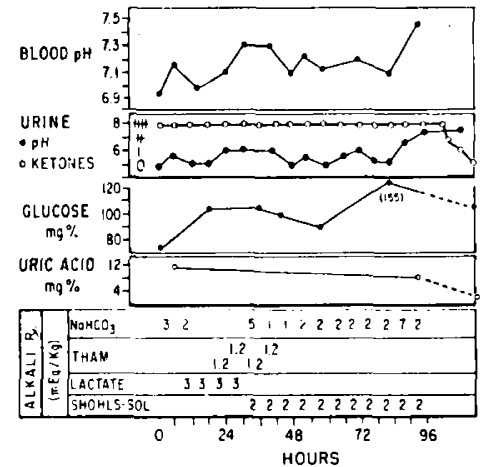

Fig. 1. The initial episode of ketoacidosis in patient CC is summarized illustrating changes in blood and urine $\mathrm{pH}$ with time and alkali therapy. The rapid correction of the abnormal values at $84 \mathrm{hr}$ was followed by rapid clearing of urinary ketones beginning $12 \mathrm{hr}$ later and by an abrupt improvement in his clinical and mental status $[3,4]$.

corrected by values obtained using flasks to which TCA had been added before the substrate, or which had been autoclaved before the incubation. Results were expressed as micromicromoles of substrate converted to $\mathrm{CO}_{2}$ per milligram of protein per hour. Since corrections were not made for quenching by the $\mathrm{KOH}$ which was constant for all of the experiments, the values reported should not be considered as absolute. In this system ${ }^{14} \mathrm{CO}_{2}$ production was linear for a sixfold range in protein concentration $(0.06-0.36 \mathrm{mg}$ protein/llask) and for incubation periods of $2-5 \mathrm{hr}$. Although the cell line of the patient required more time to reach confluency or a given protein concentration than did the control lines, the oxidation rates for a given substrate were similar in cells which had been replated for 3-8 days. Since no attempt was made to measure and correct for intracellular substrate pools, these results represented minimal values.

Glucose utilization experiments were done in a similar manner, except that sterilized rubber stoppers were used to cap the flasks. At timed intervals, $0.2 \mathrm{ml}$ supernatant reaction mixture was removed and precipitated to prepare a Somogyi filtrate [23]. Glucose was measured using a glucose oxidase method [12]; lactate was measured enzymatically by dye reduction using diaphorase as a coupler [6]. Protein was determined by the method of Lowry et al. [11] on the total reaction mixture following brief sonication to ensure complete suspension of the cell protein. Since no transfer of cells was necessary cither before or after incubation, this ensured accurate determinations of protein. 


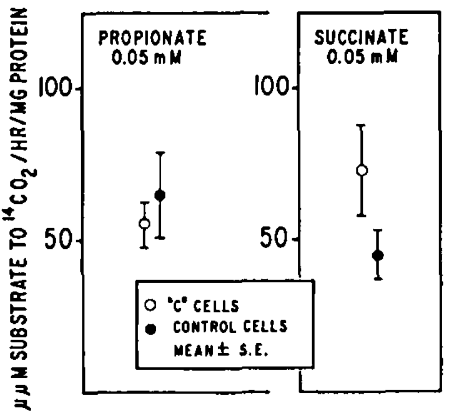

Fig. 2. Rates of radiolabeled $\mathrm{CO}_{2}$ production from ${ }^{\text {"C }} \mathrm{C}$-labeled substrates by skin fibroblasts from patient $C C(O)$ and control (๑). The results are expressed as micromicromoles of " $\mathrm{C}$-labeled substrate incorporated into $\mathrm{CO}_{2}$ per milligram of protein per hour and are the means of six or more determinations \pm SEM. The details of the method are described in the text.

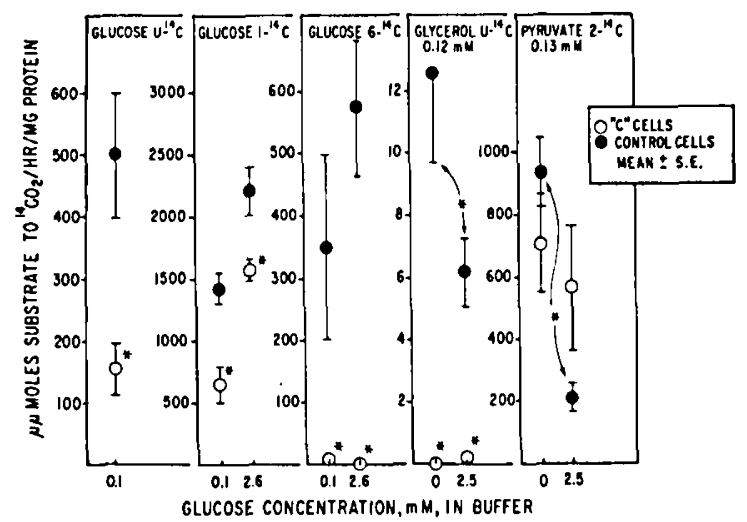

Fig. 3. Comparison of radiolabeled $\mathrm{CO}_{2}$ production rates from glucose-U-, glucose- - -, glucose-6-, glycerol-U-, and pyruvate-2- ${ }^{-14} \mathrm{C}$ by skin fibroblasts. The results are expressed as micromicromoles of "C-labeled substrate incorporated into $\mathrm{CO}_{2}$ per milligram of protein per hour \pm SF. $A$ significant difference $(P<0.05)$ between control and $C C$ lines is denoted by the asterisk.

\section{Results}

The oxidation of $0.05 \mathrm{~mm}$ concentrations of propionate- $1 \cdot{ }^{14} \mathrm{C}$ and succinate $1,4 \cdot{ }^{14} \mathrm{C}$ was $55 \pm 8$ and $73 \pm$ $16 \mu \mu \mathrm{moles} / \mathrm{mg} / \mathrm{hr}$, respectively, in $(C C)$ fibroblasts of the patient and $65 \pm 13$ and $45 \pm 8.0 \mu \mu$ moles/ $\mathrm{mg} / \mathrm{hr}$, respectively, in control cells (Fig. 2). These oxidation rates were comparable to those reported by others when estimated corrections for substrate concentrations are made $[15,20,21]$. The results indicate that the oxidation rates of propionate and succinate were essentially the same in cells from the patient $(C C)$ and in control cells.

In contrast, the rates of glucose and glycerol oxidation by cells from the patient were strikingly different from the rates of oxidation of these substrates by control cells. The oxidation of glucose-U-14 $\mathrm{C}$ was significantly less in patient cells than that in control lines $(155 \pm 40$ versus $500 \pm 100 \mu \mu$ moles $/ \mathrm{mg} / \mathrm{hr}, \mathrm{P}<0.005$ ) (Fig. 3), and carbon-specific labeled glucose at either 0.1 or 2.6 mi final glucose concentrations demonstrated even more striking differences between these cells. Whereas the incorporation of label into $\mathrm{CO}_{2}$ from glucose-C-1 was $45-65 \%$ of the control, there was essentially no $\mathrm{CO}_{2}$ produced from glucose-C-6 by cells of the patient (Fig. 3). Similarly, glycerol-U. ${ }^{14} \mathrm{C}$ was not metabolized to ${ }^{14} \mathrm{CO}_{22}$ by patient cells, but in control cells the rate of oxidation of this substrate was $12.6 \pm 1.9 \mu \mu$ moles/ $\mathrm{mg} / \mathrm{hr}$ in the absence of added glucose and $6.2 \pm 1.1$ $\mu \mu \mathrm{moles} / \mathrm{mg} / \mathrm{hr}$ in the presence of $2.5 \mathrm{~mm}$ glucose, respectively (Fig. 3). The rate of pyruvate oxidation by patient cells was not significantly different from the oxidation of this substrate by control cells in the absence of glucose. The addition of unlabeled glucose to the reaction mixture resulted in a clecrease in the oxidation of pyruvate-2.14 $\mathrm{C}$ by control cells from $940 \pm$ 110 to $210 \pm 45 \mu \mu$ moles $/ \mathrm{mg} / \mathrm{hr}(\mathrm{P}<0.001)$ but not by patient cells (710 versus $590 \mu \mu \mathrm{moles} / \mathrm{mg} / \mathrm{hr}$ ) (Fig. 3).

Studies of glucose utilization over prolonged periods of incubation revealed striking differences between the fibroblasts from the patient and the controls. During the first $18 \mathrm{hr}$, the control cells removed $50 \%$ of the substrate glucose, whereas the patient cells showed essentially no glucose consumption. Thereafter, glucose was rapidly utilized by cells from the patient (Fig. 4).

The concentration of lactate measured in a similar experiment was $9.1,5.3$, and $2.42 \mu$ moles $/ \mathrm{mg}$ protein at 12,18 , and $23 \mathrm{hr}$ in flasks with control cells, respectively. The amount with patient cells was $2.9,0.9$, and $0.0 \mu \mathrm{mole} / \mathrm{mg}$ protein for comparable periods. The lactate produced by patient cells was always $20-33 \%$ the amount produced by the control cells and this difference in the initial lactate production by the patient

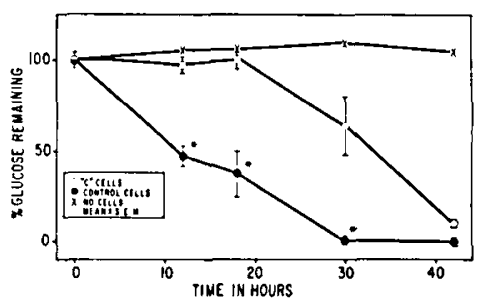

Fig. 4. Glucose uptake by skin fibroblasts from paticnt cells (O) and control cells $(\bullet)$. The results are expressed as per cent of the initial glucose concentration \pm S.E. remaining in the medium at various times. Differences between control and $C C$ cclss of $P<0.05$ are denoted by the asterisk. 
cells compared with controls was very similar to the difference in glucose utilization.

The results of the utilization of glucose as well as the specific oxidation of ${ }^{14} \mathrm{C}-1$ and ${ }^{14} \mathrm{C}-6$ glucose, glycerol$\mathrm{U}-{ }^{14} \mathrm{C}$, and pyruvate-2.14 $\mathrm{C}$ suggest an altered metabolism between glyceraldehycle-3-phosphate and pyruvate in the patient fibroblasts.

\section{Discussion}

Recurrent infantile ketoacidosis is an uncommon phenomenon usually associated with a specific defect in metabolism, e.g., glycogen storage disease type I [16], diabetes mellitus [16], methylmalonic acidemia $[5,8$, $13,19]$, or ketotic glycinemia [1, 2, 13]. In glycogen storage disease and diabetes mellitus, the values for blood glucose are abnormal. In our patient, the levels were always within normal ranges [4]. As with patient $C C$, the clinical course of infants with methylmalonic acidemia and ketotic glycinemia is characterized by severe ketoacidosis, vomiting, lethargy, and flaccidity, which are aggravated by dietary protein and stress [13]. In addition, however, long-chain ketones are present in the urine of patients with these metabolic abnormalities [17], and there is an intolerance to methionine, threonine, isoleucine, and valine in both conditions $[1,8,13]$ and a specific intolerance to leucine in ketotic glycinemia $[1,19]$. Our patient showed neither the degree of developmental failure nor the neutropenia and the thrombocytopenia reported in these conditions. The ketones excreted in his urine were $\beta$-hydroxybutyrate, acetone, and acetoacetic acid, compounds which are usually associated with starvation. Thus, the illness manifested by this infant differed clinically from the reported syndromes of infantile ketoacidosis $[3,4]$.

Our studies of skin fibroblasts obtained from the patient and from control infants provided additional data which inclicate that the metabolic defect of the patient has not been previously described. Propionate oxidation is defective in white cells [8] and skin fibroblasts $[15,20,21]$ of patients with ketotic glycinemia and methylmalonic acidemia. Skin fibroblasts from our patient oxidized this substrate at a rate comparable to that of normal cells, thus excluding these two disorders. Studies of methylmalonyl-CoA isomerase metabolism by liver tissue of the patient obtained postmortem also confirmed that his clisease was not methylmalonic acidemia [4].

Clinical ketosis may be a result of either overproduction $[10,18]$ or underutilization [10] of ketones or both. The oxidation of acetoacetate by a muscle mince $[3,4]$ at rates comparable to that of control muscles indicated that there had not been a complete elimination of ketone metabolism. This result, coupled with the brisk ketogenic response seen clinically, suggests an intact fatty acid catabolic pathway. It does not, however, provide information on the maximal activity of the ketone-utilizing systems operative in vivo.

In most clinical situations accompanied by ketosis there is deprivation of carbohydrate, either absolutely (starvation) or relatively (diabetes mellitus, glycogenosis I) $[5,10,18]$. In patient fibroblasts, the lack of glucose utilization as well as the lack of incorporation of glucose- $6{ }^{-14} \mathrm{C}$ into ${ }^{14} \mathrm{CO}_{2}$ implied an inhibition of glucose metabolism. A similar reduction in glycerol-U${ }^{14} \mathrm{C}$ oxiclation compared with the normal pyruvate-2${ }^{14} \mathrm{C}$ to ${ }^{14} \mathrm{CO}_{2}$ conversion suggested that this inhibition exists between glyceraldehyde 3-phosphate and pyruvate. Further support for this hypothesis was the lack of suppression of pyruvate-2.14 $\mathrm{C}$ oxidation in the patient cells by added unlabeled glucose. The reduced glucose uptake by the patient cells during a 12- to 18-hr incubation was also cogent evidence for the proposed hypothesis. The oxidation of glucose-1-14 $\mathrm{C}$ by patient cells at a rate $45-65 \%$ of control cells would all but rule out an alteration in permeability or transport as being the primary cause of the reduced oxidation of the glucose labeled on the sixth carbon.

The results of the metabolic investigation in cells derived from a patient with an abnormal propensity to develop ketoacidosis reemphasize that normal glycolysis is important in the consumption of ketones peripherally [9]. Others have suggested that the pyruvate supply and the rate of fatty acid oxidation greatly affect intracellular distribution of citric acid cycle intermediates and thereby alters the course of intermediary metabolism [10, 18, 22, 26]. Physiologic observations of human starvation ketosis [17] have not yet clarified the control mechanisms involved in this process $[10,17$, 18]. The apparent correlation between inhibited glycolysis in the fibroblasts and malregulation of ketone production and/or utilization in this child requires an evaluation of substrate requirements and enzyme patterns in various tissues. Recent studies have indicated the possibility of pyruvate kinase activation and inhibition as regulatory mechanisms of glycolysis $[1,25]$ and preliminary experiments have shown a reduction in several glycolytic enzyme activities in muscle and fibroblasts from our patient [7]. These studies will be the subject of a later communication. 


\section{Summary}

Studies of fibroblasts obtained from an infant with heretofore undescribed form of ketoacidosis have revealed an inhibition in oxidation of glucose-6-14 $\mathrm{C}$ and glycerol-U-14 $\mathrm{C}^{10}{ }^{14} \mathrm{CO}_{2}$, whereas the oxidation of pyruvate, succinate, and propionate did not differ from that of control cell lines. When examined in conjunction with the clinical course, these studies excluded the known syndromes of infantile ketoacidosis. These findings suggest that the ketosis might be associated with inhibition in glycolysis.

\section{References and Notes}

1. Cinleds, B., And Nyhan, W. L.: Further observations of a patient with hyperglycinemia. Pediatrics, 33: 403 (196:1).

2. Childs, B., Nirhan, W. L., Borden, M., Bakd, L., and Cooke, R. E.: Idiopathic hyperglycinemia and hyperglycinuria; a new disorder of amino acid metabolism. Pediatrics, 27: 522 (1961).

3. Coknblath, M., Morkow, G., Barness, L. A., Fleming, G. A., Gingell, R. L., ANd Leffler, $A$. T.: $A$ new syndrome of ketoacidosis in infancy (Abstract). Presented at the Fourtieth Annual Meeting of the Society for Pediatric Research, Atlantic City, ‥ J., May 1, 1970.

4. Cokniblath, M., Tildon, J. T., Gingell, R. L., Fleming, G. A., AND LEFLER, A. T.: Unpublished data.

5. Coknblath, M., ann Schwartz, R.: Disorders of glycogen metabolism. In: Disorders of Carbohydrate, Metabolism in Infancy, p. 115 (W. B. Saunders Company, Philadelphia, 1966).

6. Frieilland, I. M., ANd Dietrich, L. S.: A rapid enzymatic determination of L(t)-lactic acid. Anal. Biochem., 2: 390 (1961).

7. Gingell, R., Tildon, J. T., Cokniblath, M., and Leffler, A.: A new syndrome of keto-acidemia in infancy. Proc. Central Soc. Clin. Res., 13: 93 (1970).

8. Hsin, Y. E., Skclly, K. J., And Roseniberg, L. E.: Defective propionate carboxylation in ketotic hyperglycinemia. Lancet, i: 757 (1969).

9. Ide, T., Steinke, J., AND CahlLl, G. F., JR.: Metabolic interactions of glucose, lactate and $\beta$-hydroxybutyrate in rat brain slices. Amer. J. Physiol., 217: 784 (1969).

10. Kkens, H. A.: The regulation of the release of ketone bodics by the liver. Advan. Enzyme Regul. t: 339 (1966).

11. Lowky, O. H., Rosebrough, N. J., Fakr, A. L., ANd Randall, R. J.: Protein measurement with the folin phenol reagent. J. Biol. Chem., 193: 265 (1951).

12. MIARKs, V.: An improved glucose oxidase method for determining blood, csf, and urine glucose levels. Clin. Chim. Acta, 4: 395 (1959).

13. Mokrow, G., Barness, L. A., Auerbach, V. H., DiGgorge, A. M., ANdo, T., and Nyhan, W. L.: Observations on the coexistence of methylmalonic acidemia and glycinemia. J. Pediat., 74: 680 (1969).

14. Morrow, G., Barness, L. A., Cardinale, G. J., Abeles, R. N., and Flaks, J. G.: Congenital methylmalonic acidemia; enzymatic evidence for two forms of the disease. Proc. Nat. Acad. Sci. U.S. A., 63: 191 (1969).

15. Morrow, G., Mellaian, W. J., Barness, L. A., and Dimitrow, N. V.: Propionate metabolism in cells cultured from a patient with methylmalonic acidemia. Pediat. Res., 3: 217 (1969).

16. Orerholzer, V. G., Levin, B., Burgess, E. A., and Young, W. F.: Methylmalonic aciduria-an inborn error of metabolism leading to chronic metabolic acidosis. Arch. Dis. Childhood, 42: 492 (1967).

17. Owen, O. E., Felig, P., Morgan, A. P., Wahren, J., AND CAnit., G. F., Jk.: Liver and kidney metabolism during prolonged starvation. J. Clin. Invest., \&8: 574 (1969).

18. ReYnolds, A. E., AND Canill, G. F., JR.: Diabetes mellitus. In: B. Stanbury, J. B. Wyngarden, and D. S. Fredrickson: The Metabolic Basis of Inherited Discase, ed. 2, p. 51 (McGrawHill, New York, 1966).

19. Rosenberg, L. E., Lilljeqvist, A., And Hsis, Y. E.: Methylmalonic aciduria: an inborn error leading to metabolic acidosis, long-chain ketonuria, and intermittent hyperglycinemia. New Engl. J. Med., 278: 1319 (1968).

20. Roseniberg, L. E., Lilljequist, A., ANd Hsia, Y. E.: Methylmalonic aciduria. Metabolic block localization and vitamin $B_{13}$ dependency. Science, 162: 805 (1968).

21. Rosenherg, L. E., Lilljeqvist, A., Hsia, Y. E., ANd RosensLoom, F. M.: Vitamin $\mathrm{B}_{12}$ dependent methylmalonic aciduria: defective $\mathrm{B}_{12}$ metabolism in cultured fibroblasts. Biochem. Biophys. Res. Commun., 37: 607 (1969).

22. Scrutton, M. C., AND UTter, M. F.: The regulation of glycolysis and gluconeogenesis in animal tissues. Ammu. Rev. Biochem., 37: 250 (1968).

23. Somogy, M.: Determination of blood sugar. J. Biol. Chem., 160: 69 (1945).

24. Unbreir, W. W.: The absorption of carbon dioxide. In: W. W. Umbreit, R. H. Burris, and J. F. Stauffer: Manometric Techniques, ed. 4, p. 12 (Burgess Publishing Company, Minneapolis, 1964).

25. Weber, G.: Regulation of pyruvate kinase. Advan. Enzyme Regul. 7: 15 (1970).

26. Williamson, J. R., Scholz, R., and Browning, E. T.: Control mechanisms of gluconeogenesis and ketogenesis. II. Interactions between fatty acid oxidation and the citric acid cycle in perfused rat liver. J. Biol. Chem., 2ft: 4617 (1969).

27. Eagle's MIEM, Grand Island Biological Company, Grand Island, N. Y.

28. Kontes Glass Company, Vineland, N. J.

29. Specific activity, $5 \mathrm{mCi} / \mathrm{mm}$. New England Nuclear Corporation, Boston, Mass.

30. Informed consent was obtained from the parents.

31. The authors wish to express appreciation to DR. BERnice Sigman and Mrs. BetTe Krause for their assistance in adapting and maintaining the cells in tissue culture.

32. Supported in part by Grant no. IU-TC27 from the Bressler Research Foundation and Grant no. HD-03959-02 from the National Institute of Child Health and Human Development.

33. Requests for reprints should be addressed to: J. T. TiLdon, PH.D., Department of Pediatrics, University of Maryland Hospital, 22 South Greene Strect, Baltimore, Md. 21201 (USA). 